\title{
Sote-maratonin loppusuora
}

Sosiaali- ja terveydenhuollon uudistusmaraton on keväällä 2018 jälleen loppukilometreillään. Aikaisemmilla yrityskerroilla matka on jäänyt kesken, eikä nytkään voi olla täysin varma siitä, jaksaako hanke maaliin asti. Väsymys painaa niin valmistelijoita, poliittista päättäjää kuin sote-maratonia seurannutta äänestäjäkuntaakin. Tässä maratonissa on kuitenkin kysymys vasta näyttöjen antamisesta varsinaista kisaa varten. Todelliset tulokset saadaan, kun järjestelmä on 2020-luvulla saatu käyttöön ja sen tuottamaa terveyttä ja hyvinvointia verrataan muiden maiden järjestelmiin.

Kuten aina, kisaan ollaan oltu menossa suurin tulostavoittein. Tavoitteena on ollut maailman paras sosiaali- ja terveydenhuollon järjestelmä, jossa palvelujen saatavuus ja laatu paranevat, asiakaslähtöisyys lisääntyy, terveyserot pienenevät ja kustannusten kasvu taittuu. Kaikkea hyvää on siis kansalle luvattu. Väliaikoja seuranneelle katsojalle on kuitenkin jo jonkin aikaa näyttänyt sille, että alun toiveista huolimatta ennätys ja huippuaika jäävät kisassa saavuttamatta. Tulospettymyksen syynä ovat seuraavassa esitetyt asiat.

Uudistuksen lähtökohtana on ollut järjestäjän ja tuottajan erottaminen. Tällaiseen malliin velvoittava kirjaus on Sipilän hallituksen hallitusohjelmassa, vaikka kokemukset malleista, joissa järjestäjä ja tuottaja on erotettu, eivät ole olleet tuon malliin käyttöön kannustavia $(1,2)$. Mallia kokeilleet maat (esim. Uusi-Seelanti ja IsoBritannia) ovat itse asiassa tästä mallista luopuneet. Suomen kaltaisessa pienessä maassa asiantuntijaresurssien käyttö kaksinkertaiseen hallintoon, jossa osa asiantuntijoista tilaa ja osa asiantuntijoista tuottaa, johtaa helposti vaikeasti korvattavan resurssin hukkakäyttöön. Omana kansallisena vahvuutenamme on lisäksi ollut hyvin koulutettu ja korruptoitumaton virkamieskunta, joka ei ole tarvinnut erillistä kontrollitasoa ("järjestäjää”) hallintoon yleisen edun toteutumista valvomaan. Onkin suurena vaarana, että soteuudistuksessa ehdotettu malli lisää järjestelmä- tason byrokratiaa ja nostaa transaktiokustannuksia merkittävästi.

Sote-uudistukseen liitettyä valinnanvapautta on perusteltu palvelujen saatavuuden paranemiselle. On totta, että valinnanvapaus voi lisätä varsinkin perusterveydenhuollon palvelujen saatavuutta. Ehdotettu valinnanvapauden malli kuitenkin kohdentaa palveluja huonosti niille väestöryhmille, jotka palveluista eniten hyötyisivät. Kokemukset valinnanvapaudesta naapurimaastamme Ruotsista osoittavat, että valinnanvapaus ei takaa haja-asutusalueiden peruspalveluiden säilymistä ja että kaupungeissakin se voi johtaa palvelujen ylituottamiseen alhaisen sairastuvuusriksin väestöryhmille (3). Valinnanvapaus onkin hyvin huono keino sosioekonomisten erojen aiheuttamien terveyserojen pienentämiseen, kuten tässä lehdessä julkaistu sote-asiantuntijaryhmän jäsenten lausunto osaltaan selvittää (4). Pahimmillaan valinnanvapaus markkinaehtoisesti toimivassa sote-järjestelmässä kasvattaa väestöryhmien terveyseroja.

Sosiaali- ja terveydenhuollon integraatio on tehokkain tapa huolehtia kustannustehokkaasti paljon palveluja tarvitsevista asiakkaista/potilaista (5). Se on myös tehokas tapa ehkäistä riskihenkilöiden syrjäytymistä ja työkyvyttömyyttä. Sote-uudistuksessa integraatio tapahtuisi perustasolla hyvin puutteellisesti. Paljon palveluja tarvitsevien ryhmien osalta integraatiota vaikeuttaa palvelukokonaisuuksien pilkkominen pakollisilla asiakasseteleillä tuotettaviin osiin. On epätodennäköistä, että monisairaat potilaat taikka hoivaa tarvitsevat vanhukset olisivat kykeneviä itsenäisesti rakentamaan asiakasseteleistä mielekkäitä palvelukokonaisuuksia. Ehdotettu järjestelmä sitookin merkittävästi resursseja asiakasohjaukseen ja asiakassuunnitelmien laatimiseen, mikä resurssi on sitten poissa varsinaisesta palvelutuotannosta.

Sote-uudistuksen taustalla kummittelee valtiovarainministeriön pyrkimys sosiaali- ja terveydenhuollon kustannusten kasvun hillintään (6). 
Tämä tavoite aiotaan toteuttaa tiukalla kehysbudjetoinnilla. Kustannusten hillintää vaikeuttaa kuitenkin Suomen perustuslaki, joka takaa jokaiselle riittävät sosiaali- ja terveydenhuollon palvelut. On vaikea uskoa, että väestön vanhetessa ja palvelutarpeen kasvaessa valtiovarainministeriön mahtikäskyllä voitaisiin palvelutarvetta vähentää. Sosiaalipoliittisesti ajatus palvelujen leikkaamisesta, kun palvelutarve kasvaa, on melko lailla järjetön. Kustannusten kasvun hillitsijäksi on ministeriön ajatuspajoissa suunniteltu digitalisaation tuomia valtavia (3 miljardin euron) kustannussäästöjä, vaikka näytöt tällaisista säästöistä sosiaali- ja terveydenhuollon osalta puuttuvat. Onkin pelättävissä, että kehysbudjetin puristuksessa palvelujen tasoa leikataan tai palvelujen kustannuksia katetaan nousevilla asiakasmaksuilla. Näiden vaikutukset väestön terveyteen ja hyvinvointiin taikka terveyseroihin voivat olla täysin sote-uudistuksen perustavoitteiden vastaisia.

Sote-uudistuksen kautta syntyvä järjestelmä näyttäytyy asiantuntijoillekin hyvin monimutkaisena. Monikanavarahoitus yhdistyy siinä monituottajamalliin. Ministeriön virkamiesten dokumenteissa uskotaan syntyvän uuden ekosysteemin itseohjautuvuuteen, vaikka järjestelmän markkinaehtoistamisella on haluttu luoda kilpailua ja synnyttää uutta yritystoimintaa. Nämä mekanismit tyypillisesti heikentävät toimijoiden yhteistoimintaa ja vähentävät järjestelmän koordinaation mahdollisuuksia. Kokonaisuutena uusi järjestelmä onkin hyvin vaikeasti ohjauttava, mikä heikentää tulevaisuudessa mahdollisuuksia kohdentaa sosiaali- ja terveydenhuollon resursseja väestön muuttuvien terveys- ja hyvinvointitarpeiden mukaisesti.

Suomen nykyinen terveydenhuoltojärjestelmä on pärjännyt kansainvälisissä vertailuissa kokonaisuutena hyvin $(7,8)$. On siksi lupa odottaa, että uudistukseen lähdettäessä sijoitus tilastoissa ei ainakaan alene. Kuten urheilussa, myös soteuudistuksessa on onnistumista mahdollista arvioida suhteessa siihen, kuinka hyvin suorittaja on hyödyntänyt omia kyvykkyyksiään. Suomessa on paljon tietoa sosiaali- ja terveydenhuollon toiminnasta. Meillä on myös näyttöä siitä, mitkä asiat tuottavat sote-uudistuksessa toivottuja tuloksia. Kovin hyvin näitä tiedollisia valmiuksia ei ole osattu tai haluttu soten valmistelussa hyödyntää. Poliittinen ohjaus ja ideologia on toistu- vasti asetettu asiantuntemuksen ja tiedon edelle. Kysymys on tällöin järjestelmätason uskomushoidosta.

Järjestelmäuudistuksellakin on oma placeboefektinsä, kun sosiaali- ja terveydenhuollon henkilöstö joutuu muutoksessa hetkeksi luupin alle, mikä yleensä merkitsee ainakin hetkittäistä toiminnan tehostumista. Säilyykö tällainen vaikutus, on sitten ihan toinen juttu. Pahinta on, jos uudistuksen takia joudutaan aikaisempaa huonompaan tilanteeseen, kun oikea hoito ongelmiin on väärän lääkkeen käytön takia viivästynyt ja kokonaistilanne vaikeutunut. Siksi sote-maratonissa ei nyt voi luovuttaa, vaan on yhä jaksettava ponnistella sellaisen järjestelmän aikaansaamiseksi, joka pystyy tulosodotuksiin vastaamaan.

\section{LÄHTEET}

1) Tynkkynen L-K, Keskimäki I, Lehto J: Purchaserprovider splits in health care-The case Finland. Health Policy 2013,111:221-225. https://doi.org/10.1016/j.healthpol.2013.05.012

2) Iacobucci G: Abolishing purchaser-provider split helped New Zealand scheme to cut costs, says King's Fund. BMJ 2013 347:f5503. https://doi.org/10.1136/bmj.f5503

3) Luotonen N. Valinnanvapaus asukkaan ehdoilla - Suomen edellytykset Ruotsin kokemusten ja kansainvälisen tutkimustiedon valossa. Luettu 13.1.2018. https://www.hanken.fi/sites/default/files/ atoms/files/valinnanvapaus_asukkaan_ehdoilla_ hccg.pdf

4) Lehtonen L, Hiilamo H, Erhola $\mathrm{M}$ et al. Valinnavapaus sote-uudistuksessa. Sosiaalilääket. aikakausilehti 2018: 55: 76-85.

5) Terveyden ja hyvinvoinnin laitos. Sote-palvelujen integraatio. Luettu 31.1.2018 https://www.thl.fi/ fi/web/sote-uudistus/palvelujen-tuottaminen/sotepalveluiden-integraatio

6) Hetemäki M. Sote-uudistus on välttämätön palvelujen turvaamiseksi, Valtioneuvosto. Luettu 31.1.2018 http://vm.fi/artikkeli/-/asset_publisher/ sote-jarjestelmaa-pitaa-uudistaa-palvelujenturvaamiseksi

7) Euroopan komissio. State of health in the EU - Suomi - Maan terveysprofiili 2017. Luettu 13.1.2018. https://ec.europa.eu/health/sites/health/ files/state/docs/chp_fi_finnish.pdf

8) OECD. Health at a glance - How does Finland compare? OECD 2015, 1-2. Luettu 28.1.2019. https://www.oecd.org/finland/Health-at-a-Glance2015-Key-Findings-FINLAND.pdf

\section{LASSE LEHTONEN}

professori, hallintoylilääkäri

Helsingin yliopisto ja HUS 